\title{
Developing Speaking Board Game of Descriptive Text at MAN 1 Medan
}

\author{
Hamka Ade ${ }^{1}$ \\ ${ }^{1}$ Pendidikan Bahasa Inggris Universitas Negeri Medan \\ Medan, Indonesia \\ 1adehamka98@gmail.com
}

\begin{abstract}
The aim of this study is to develop a learning media on teaching Descriptive Text at MAN 1 Medan. This study was conducted by Research \& Development (R\&D) design. The source of the data are the students of MAN 1 Medan which consists of thirty two students. To collect the data, the online questionnaires to the students of MAN 1 Medan was shared to obtain the students' needs of learning media of descriptive text in the classroom and conducted an interview with the classroom teacher. There are some steps should be done to develop a learning media: Evaluation and Needs Analysis, Learning Media Design, Learning Media Development, Validation by Experts, Revision and Final Product. After doing the Evaluation and Needs Analysis, it is found that the existing learning media used in the classroom to teach Descriptive Text is not interesting for most students and unable to enhance their ability especially in Speaking skills. It can be shown from the result of the questionnaire that $87.5 \%$ of students need a learning media to help them in improving their ability in English especially in descriptive text topic, and $46.9 \%$ of students prefer Speaking Board Game as their learning media. The product has been validated by the experts namely English lecturer and English teacher. The product result was Speaking Board Game which is modifying Snake and Ladder game that is acclimated with the basic competence of K13. The result of experts' validation showed that the media was an appropriate media to be used on speaking descriptive text by obtaining the average percentage $95.1 \%$ or categorized as excellent.
\end{abstract}

Key words : Research and Development, Learning Media, Descriptive Text, Speaking Board Game

\section{INTRODUCTION}

English as a language has four

competencies to learn consisting of two major language skills which are productive skills and receptive skills. the skills that are included into productive skills are speaking and writing; and the receptive skills are reading and listening. In order to achieve the fluency of English the students must be able to do those four skills well. As the matter of fact, still many teachers only focus on certain skills in teaching English to the students. For instance, in Indonesia many teachers only focus on reading and listening because those two skills are examined in the national examination. Therefore, the teachers leave those two other skills and only focus on reading and listening. The phenomenon has made the students become passive in English. The students' speaking skills is not improving since they have no space to explore their speaking skills. easy yet important, because no matter what language that is learned the goal of the language itself is to make the students are able to communicate and express their thoughts, feelings and opinions to the people. A teacher has to make English as a habit in order to stimulate the students' motivation and encouragement to learn English more. Because, learning English is still considered as a hard and not enjoyable thing to do for most students in Indonesia. Consequently, a teacher must put English into a communicative and enjoyable learning process that will enhance the students' motivation that at the end will be improving their English skills especially Speaking.

There are several factors that can cause this happening such as the teaching delivery done by the teacher that too focus on certain skills e.g reading or listening, the learning materials or the learning media that the teacher provides. For instance, when 
teaching Descriptive Text the teacher tends to set the materials to focus on the reading and writing skills only without integrating the other two skills which are listening and speaking. This has made the students only understand the generic structure and linguistic feature of the Descriptive Text and not able to communicate that in their daily life.

In this research, the focus of the study is the learning media that the teacher uses in teaching Descriptive Text. Because based on Li-Ling Kuo states that a medium is called the educational medium when the medium transfers message for teaching (Li-Ling. 1996). He adds that the use of media is important and it is impossible to coordinate teaching with learning without using media (LiLing.1996). Media are flexible because they can be used for all level of students and in all subjects. Teaching media also can encourage students to take more responsibility for and control over their own learning, engage in joint planning of the syllabus, and take longer-term perspectives on their own learning (Masterman. 1999). Since media give many advantages, a teacher should consider a medium to be used in teaching- learning process.

As the matter of fact, still there are many teachers are lack of creativity to design a good learning media that is able to enhance the students' speaking skills. Especially in teaching Descriptive Text as what has been mentioned above.

The paragraph above is evidenced by the achievement of the students in English speaking activity especially in speaking decsriptive text. The table below demonstrates that only a half of the population who succeed the teaching and learning process. The table below shows the sixteen out of thirty two students who obtained the score under determined KKM (Minimum Mastery Criteria). The speaking activity is measured by these following criteria : pronunciation, intonation, fluency and accuracy. The highest score for each criteria is twenty five. Based on the syllabus the score range is as follow : 86-100 (Excellent), 71-85 (Good), 56-70 (Fair), and $<55$ (Poor).

Table.1 Students' Study Report

\begin{tabular}{|c|c|c|c|c|c|c|c|}
\hline \multirow[b]{2}{*}{ No } & \multicolumn{7}{|c|}{ Indicator } \\
\hline & Name & Pronunciation & Intonation & Fluency & Accuracy & Total & Predicate \\
\hline 1 & AFWAN FADHILAH & 15 & 15 & 10 & 10 & 50 & Poor \\
\hline 2 & AINA SARI & 20 & 20 & 15 & 15 & 70 & Fair \\
\hline 3 & $\begin{array}{l}\text { ALBANA FIKRI } \\
\text { TANJUNG }\end{array}$ & 12 & 12 & 10 & 10 & 54 & Poor \\
\hline 4 & AMANDA ZAHRA & 18 & 15 & 15 & 15 & 63 & Fair \\
\hline 5 & $\begin{array}{l}\text { ANDINA PUTRI } \\
\text { RAMADANI HARAHA }\end{array}$ & 15 & 15 & 10 & 10 & 50 & Poor \\
\hline 6 & ANNISA ANGKAT & 16 & 16 & 17 & 17 & 66 & Fair \\
\hline 7 & ARIA FALWAGUNA & 12 & 12 & 10 & 10 & 54 & Poor \\
\hline 8 & AUTA SHINTA SARAH & 16 & 15 & 10 & 10 & 51 & Poor \\
\hline 9 & DAFFA ADILLAH HSB & 15 & 15 & 10 & 10 & 50 & Poor \\
\hline 10 & $\begin{array}{l}\text { DAFFRIL SYIFA } \\
\text { ASHAKI }\end{array}$ & 20 & 20 & 15 & 15 & 70 & Fair \\
\hline 11 & DWI AMANDA & 20 & 20 & 15 & 15 & 70 & Fair \\
\hline
\end{tabular}




\begin{tabular}{llcccccc}
\hline No & \multicolumn{1}{c}{ Name } & Indicator & & Total & Predicate \\
& & Pronunciation & Intonation & Fluency & Accuracy & & \\
\hline & TAMBUNAN & & & & & & \\
12 & EZRA NABILA NST & 15 & 15 & 10 & 10 & 50 & Poor \\
13 & FAREL DINATA & 15 & 15 & 15 & 15 & 60 & Poor \\
14 & HABIBI IRAWAN & 18 & 18 & 17 & 17 & 70 & Fair \\
& HAURA RIFQA & 18 & 15 & 15 & 15 & 63 & Fair \\
& HASCARJANI & & & & & & \\
16 & MUHAMMAD ARYA & 16 & 16 & 17 & 17 & 66 & Fair \\
\hline
\end{tabular}

The table above has led this study to the urgency of the development of a new media which enables to facilitate and improve the students' ability in speaking descriptive text since a half of the population still achieve the score in the range below the KKM (Minimum Mastery Criteria). Additionally, a teaching and learning process can be considered as success if the results of the study can reach $75 \%$ of the population. Based on what is stated by Syaiful Bahri Djamarah and Aswan Zain (2006: 107), if the teaching and learning process reaches less than $60 \%$ of the population, it is considered as poor.

The learning media in this study namely "Speaking Board Game" is developed based on the students' needs and the preliminary data obtained from the achievement of students' learning in speaking descriptive text as mentioned above.

The media used by the teacher in teaching is called "Realia', where the teacher displays some pictures about tourist attractions and historical places and ask the students to mention some words related to the places displayed. It is proven ineffective based on the learning result. Additionally, the students still experience difficulties in describing the places, therefore, they need a learning media which enables to assist them in describing the topic in more fun in interesting way that in turn will activate their English.

The media developed in this study provides a different learning exposure that the students will be assisted to actively use English by the clues (words hints, pictures), and the media is in a form of game that must be challenging rather than individually asked to describe something with only seeing a picture. This game is also divided into two main sections which are the speak louder section and what did your hear section. Those will not only activate the students speaking skills, but also the listening skills; since there are also some audios provided for them to listen and write what they hear. While doing the game, the teacher can also correct the pronunciation and other aspects of speaking as stated on the table above that will lead to the fluency and the learning achievement.

The problems mentioned above have led the researcher to develop an English learning media to teach descriptive text. The development of the learning media will be discussed further.

The research findings will be beneficial for the students, teachers and other researchers as follows : (1) For the students. By using Speaking Board Game, the students will have sufficient and effective media to train their speaking skills. On the other hand, learning English will be so much fun and motivating for them by using games as their learning media.

(2) For the teachers. The teachers will have an efficient learning media that also can improve and motivate the students to love studying English. (3) For the researchers. The results of this research can be a reference for other researchers to conduct the other related research

\section{METHODS}




\section{Participants}

The participants of the research were students of first grade (class X MIA 10) of MAN 1 Medan in Academic Year 2020/2021. The participants were 32 students. Acting as the collaborator to observe the teaching media from teacher's point of view, the researcher obtained some aid from the English teacher, Nikmah Fadilah Nasution, S.Pd.

\section{Instrument}

The instruments of this research consisted of questionnaire and interview. The questionnaire was distributed online to obtain the data of students' needs and learning exposure or experience and the interview was conducted to the teacher in order to obtain the data of the existing learning media used in the classroom in teaching descriptive text.

\section{Procedure of The Research}

This research was conducted based on Educational Research and Development (R \& D) Research. This research was proposed by Borg and Gall. The aim of this research was to create new product in several stages to improve previous products by using the existing data before (Borg \& Gall, 2003:569).

Educational research and development $(\mathrm{R} \&$ D) is a process used to develop and validate educational products. The steps of this process are usually referred to as the R \& D cycle, which consists of studying research findings pertinent to the product to be developed, developing the product based on the finding, field testing it in the setting where it wil be used eventually, and revising it to correct the deficiencies found in the field testing stage. In indicate that product meets its behaviorally defined objectives.

This modification supported by Dirgeyasa (2011) explains that the procedures of development and research implementation are not strict steps that is followed; every researcher could execute and determine the proper procedures for him/her based on the condition faced during the process of development.

Therefore; in this study, the steps conducted as follows : (1) Evaluation and Needs Analysis, (2) Learning Media Design, (3) Learning Media Development, (4) Validation By Experts, (5) Revision, and (6) Final Product.

\section{(1) Evaluation and Needs Analysis}

The evaluation was done in order to know how the existing learning media affected the students' ability in speaking specifically when studying descriptive text. The need analysis was done in order to know the needs of the students in the sake of improving their speaking ability.

(2) Learning Media Design

In this stage the construction of the form of the learning media for descriptive text was designed. The learning media must cover all of the skills needed to master English such as listening, reading, writing and speaking skills.

(3) Learning Media Development

The learning media of grade tenth students was designed and developed based on the data provided in evaluation and needs analysis.

(4) Validation By Experts

In this stage, the expert judgment was used. The learning media "Speaking Board Game to teach descriptive text" was validated in terms of learning media relavancy to the syllabus or lesson plan, the learning media content (linguistic aspect), and the layout of the learning media.

(5) Revision

After the learning media produced, the learning media was validated by expert judgment; it was then revised in order to find out the good, reliable and valid in terms of theoretical standards.

(6) Final Product

In this stage, the learning media was delivered in the classroom to be tested and used by the students during the learning activity of descriptive text.

\section{Research Findings}

In developing speaking media, there were six steps need to be taken, namely (1) Gathering data and information, (2) Need analysis, (3) Media design, (4) Validating to experts, (5) Revising, and (6) Final product.

\section{Gathering data and information}

The data and information were firstly derived from the primary observation done before doing the research. The fact showed that the media researcher really not interesting and it is evidenced by the study report mentioned in the background of study (take a look at the Table 1. Students' Study Report). Additionally, the interview was also conducted to the classroom teacher in order to know the existing media used in teaching descriptive text. 
Table 4. 1 Teacher's Interview Response

No.

Answers

1. Have you ever taught

Descriptive Text in your class?

2. According to you,

what is the main objective of learning

Descriptive Text?

3. When teaching Descriptive Text,

do you find any difficulties in teaching your students?

4. How students' attitude towards the learning process in the class especially in the topic of Descriptive Text?

5. What is the most important skills in learning Descriptive Text?
Yes, I have ever taught Descriptive Text in my class.

The main purpose of learning

Descriptive Text is to make the students are able to describe and explain the things around them.

Therefore, they are able to explain and inform that to others.

Basically, all students can understand the materials given easily. But, it is a problem to them in arranging the sentences due to the lack of vocabulary mastery.

They seem enjoying the learning. I give them slide containing some pictures such as countries abroad, or others. When I display the slides, I will ask them to mention some words related to the pictures. Then I lead them to make a sentence.

In my opinion, the most important skills in Descriptive Text is writing, since in my concern when a student is 
No.

able to write; they; therefore be able

to speak it.

6. When your students tend to be bored in learning, what efforts do you do?
I do a game session such as guessing

word. One student holds a paper

containing the name of things; the

student will be given instructions

related to the word; then the other

should guess.

7. To assist the teaching of Descriptive Text in the class, do you use a learning media? If yes, what is it?
For visual media, I use projector and

show the pictures of public figures,

things, etc.

The other media I use is called Realia.

This is a concrete media and tell them

to describe the thing.

\section{Need Analysis}

The second step researcher doing the need analysis. The needs must be analyzed before developing the new media. The need analysis researcher done by distributing online questionnaire via Google Form to the students of Grade ten at MAN 1 Medan.
The questionnaire researcher given to thirty two students of grade $\mathrm{X}$ in MAN 1 Medan. Hutchinson and waters (1987) stated that in order to do the need analysis, there are three catagories of questions which should be covered, namely necessities, lacks and wants. The following tables show the students' necessities, lacks and wants for descriptive text learning media. 
Table 4. 2 Students' Necessities Analysis Media Speaking Descriptive Text

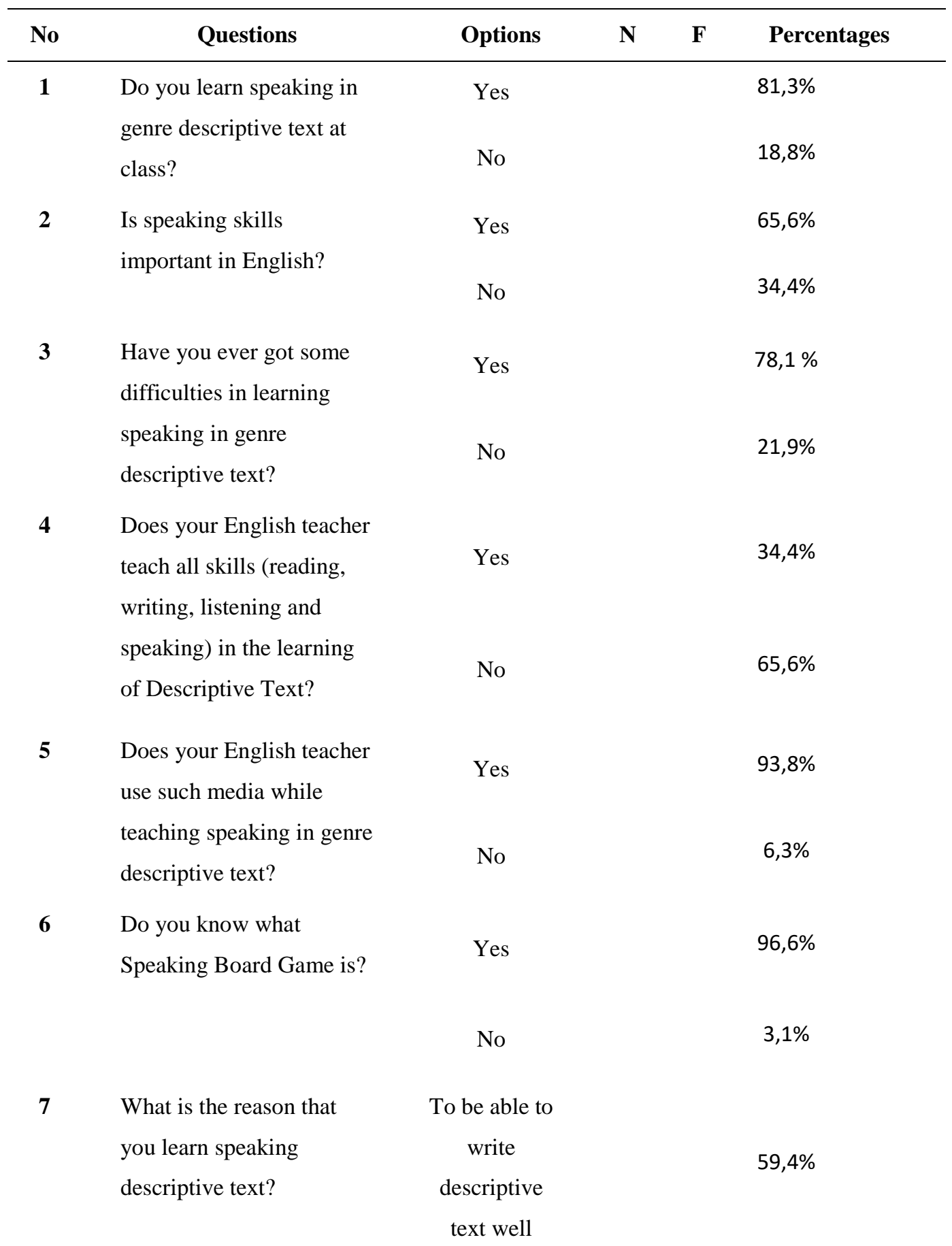




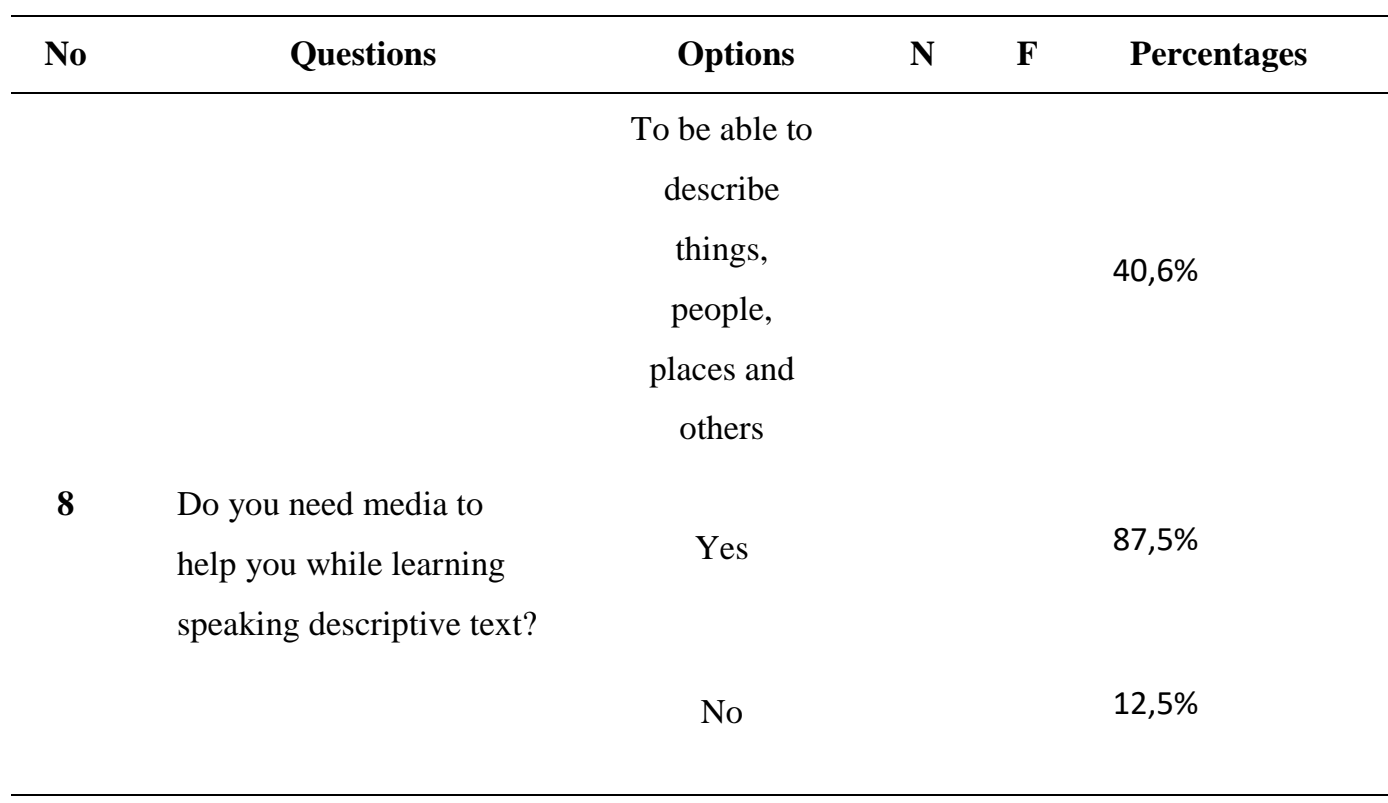

Table 4. 3 Students' Lacks Analysis Media Speaking Descriptive Text

\begin{tabular}{|c|c|c|c|c|c|}
\hline No & Questions & Options & $\mathbf{N}$ & $\mathbf{F}$ & Percentages \\
\hline \multirow[t]{2}{*}{1} & $\begin{array}{l}\text { You can write Descriptive } \\
\text { Text well, but, you can't }\end{array}$ & Yes & & & $75 \%$ \\
\hline & $\begin{array}{l}\text { describe something well. } \\
\text { Is this statement true? }\end{array}$ & No & & & $25 \%$ \\
\hline \multirow[t]{2}{*}{2} & $\begin{array}{l}\text { In English you tend to } \\
\text { be..... }\end{array}$ & Passive & & & $40,6 \%$ \\
\hline & & Active & & & $59,4 \%$ \\
\hline
\end{tabular}

Based on the above table it can be inferred that most students tend to be passive in English; therefore, they are able to write descriptive text well based on the structure and linguistic features which descriptive text has. But, they are unable to communicateit.

Table 4. 4 Students' Wants Analysis Media Speaking Descriptive Text 


\begin{tabular}{|c|c|c|c|c|c|}
\hline No & Questions & Options & $\mathbf{N}$ & $\mathbf{F}$ & Percentages \\
\hline \multirow[t]{3}{*}{1} & In learning speaking descriptive text, & PPT & 32 & 7 & $21,9 \%$ \\
\hline & you want the learning media as...... & Video & 32 & 10 & $31,3 \%$ \\
\hline & & $\begin{array}{c}\text { Speaking } \\
\text { Board Game }\end{array}$ & 32 & 15 & $46,9 \%$ \\
\hline \multirow[t]{2}{*}{2} & $\begin{array}{l}\text { According to you, if the learning } \\
\text { media in studying Descriptive Text in }\end{array}$ & Interesting & 32 & 31 & $96,9 \%$ \\
\hline & $\begin{array}{l}\text { a form of Ludo/Speaking Board } \\
\text { Game, the learning will be... }\end{array}$ & Boring & 32 & 1 & $3,1 \%$ \\
\hline \multirow[t]{4}{*}{3} & $\begin{array}{l}\text { You prefer learning media in the form } \\
\text { of... }\end{array}$ & Pictures & 32 & 3 & $9,4 \%$ \\
\hline & & Game & 32 & 17 & $53,1 \%$ \\
\hline & & Text & 32 & 2 & $6,3 \%$ \\
\hline & & Video & 32 & 10 & $31,3 \%$ \\
\hline \multirow[t]{2}{*}{4} & Will you use Speaking Board game as & Yes & 32 & 22 & $68,8 \%$ \\
\hline & the media to learn Descriptive Text? & No & 32 & 10 & $31,3 \%$ \\
\hline \multirow[t]{5}{*}{5} & What do you expect from Speaking & Speaking & 32 & 10 & $31,3 \%$ \\
\hline & Board Game can cover your skills & Writing & 32 & 2 & $6,3 \%$ \\
\hline & & Reading & 32 & 1 & $3,1 \%$ \\
\hline & & Listening & 32 & 2 & $6,3 \%$ \\
\hline & & All skills & 32 & 17 & $53,1 \%$ \\
\hline
\end{tabular}

\section{Developing Speaking Board Game to Teach Descriptive Text}

Some stages were conducted by researcher to obtain a good result of product and the stages would be described as follow.
1. Designing the layout of the Speaking Board Game

The researcher designs the layout manually by considering the squares required on the board. There will be thirty-five squares that will contain one 
instruction each. The visual will be as follow :

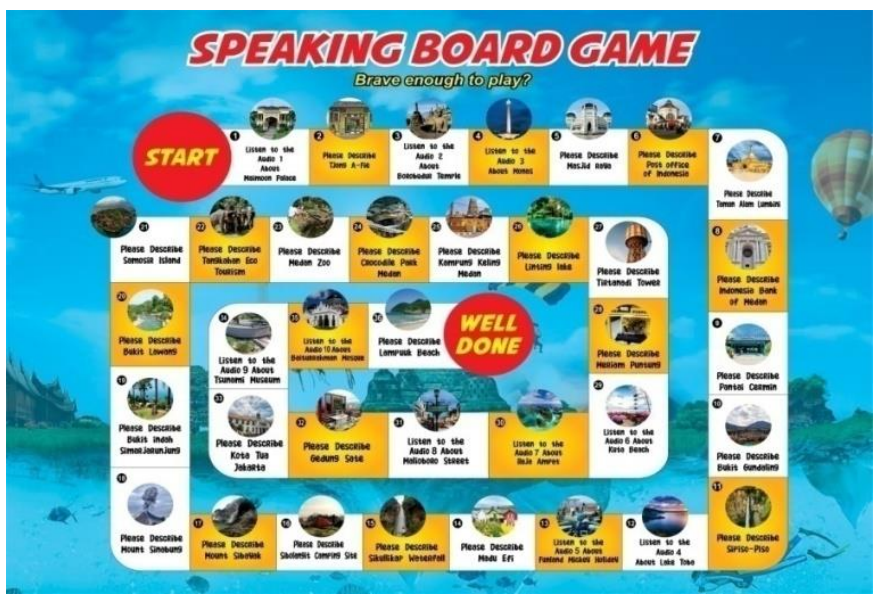

Figure 4. 1

\section{Speaking Board Game Layout}

The layout is designed by using Corel Draw, the amount of squares is considered to the students' needs and skill distribution in each squares. There is one start square and one finish square to indicate that the student has completed the game.

In each square, there is also an illustration in a form of picture of the object being described. The color chosen is as attractive as it can be in order to motivate the students' enthusiasm in learning.

In doing this game, the students will have worksheets to do during the game. The worksheets are in the form of tables to be filled by the students. The worksheets function to give final score at the end of the game.

2. Using the Product Based on Lesson Plan

Product design researcher done by reffering to the students' need analysis. The students need an interesting learning media which can help them in speaking especially in the topic of descriptive text which the goal in the syllabus is to be able to describe tourist attractions and historical places.

4. Validating by Experts
The developed media that had already been arranged by researcher were validated by experts. Experts used the questionnaire sheet to measure the appropriateness of the media developed by researcher. The measure researcher intended to know whether the developed media researcher useable or not.

The questionnaire that researcher proposed to the validator researcher made based on rating scale. Moreover, the scale could be described as followed excellent (90), good (80), fair (70), less (60), very less (50). The questionnaire researcher filled by experts Indra Hartoyo, S.Pd, M.Hum (English Lecturer in Medan State University) and Nikmah Fadillah Nasution, S.Pd (English Teacher in MAN 1 Medan). Media validation included three aspects, they were: indicator aspect, linguistic aspect, and layout aspect. For the first expert researcher English Lecturer in State University of Medan Indra Hartoyo, S.Pd, M.Hum and the second expert researcher Nikmah Fadillah Nasution, SPd. The results can be seen as follow:

Table 4. 5 The Data of Experts' Validation toward Indicator Aspect 


\begin{tabular}{|c|c|c|c|c|}
\hline \multirow{2}{*}{ Items Assessed } & \multicolumn{2}{|c|}{ Experts } & \multirow{2}{*}{$\begin{array}{c}\text { Percentages } \\
(\%)\end{array}$} & \multirow{2}{*}{ Criteria } \\
\hline & $\mathbf{I}$ & II & & \\
\hline $\begin{array}{l}\text { The curriculum competence of Speaking Board Game } \\
\text { fullfils the learning needs }\end{array}$ & 5 & 5 & 100 & Excellent \\
\hline $\begin{array}{l}\text { The Speaking Board Game is easy to use as a learning } \\
\text { media for students }\end{array}$ & 4 & 4 & 80 & Good \\
\hline $\begin{array}{l}\text { The instructions applied in Speaking Board Game in line } \\
\text { with the material in the syllabus }\end{array}$ & 4 & 5 & 90 & Excellent \\
\hline $\begin{array}{l}\text { Learning media contains topic which gives } \\
\text { competencies in conveying descriptive text orally }\end{array}$ & 5 & 5 & 100 & Excellent \\
\hline $\begin{array}{l}\text { The material given directs the students to improve the } \\
\text { competency rapidly and effectively }\end{array}$ & 4 & 5 & 90 & Excellent \\
\hline $\begin{array}{l}\text { The parts of Speaking Board Game are optimal and } \\
\text { relevant with the essentials and competencies to obtain. }\end{array}$ & 5 & 5 & 100 & Excellent \\
\hline An overall assessment & 27 & 34 & 93.3 & Excellent \\
\hline
\end{tabular}

The first aspect researcher conducted to identify whether the learning media already fulfilled the basic competencies and learning objectives of descriptive text in the syllabus or not. The data above presented that average percentage of experts' validation toward indicator aspect researcher $93.3 \%$ and categorized as excellent. In conclusion, the media especially in indicator aspect has been impressive. In addition, the competencies based on students' needs, the material and syllabus correlation, topic, material and learning objectives of the media were also categorized as excellent. Meanwhile, the (kemudahan) researcher categorized as good. Based on those criteria, the Speaking Board Game can be categorized as an appropriate media for tenth grade students to learn speaking descriptive text. 
Table 4. 6 The Data of Experts' Validation toward Linguistic Aspect

\begin{tabular}{|c|c|c|c|c|}
\hline \multirow{2}{*}{ Items Assessed } & \multicolumn{2}{|c|}{ Experts } & \multirow{2}{*}{$\begin{array}{l}\text { Percentages } \\
(\%)\end{array}$} & \multirow{2}{*}{ Criteria } \\
\hline & $\mathbf{I}$ & II & & \\
\hline $\begin{array}{l}\text { Instructions used in Speaking Board Game is easy to } \\
\text { be understood }\end{array}$ & 5 & 5 & 100 & Excellent \\
\hline $\begin{array}{l}\text { Speaking Board Game motivates the students to use } \\
\text { English actively }\end{array}$ & 5 & 5 & 100 & Excellent \\
\hline The intonation and articulation of listening audio & 5 & 5 & 100 & Excellent \\
\hline The clarity of listening audio & 5 & 5 & 100 & Excellent \\
\hline The effectivity and effeciency of listening audio & 4 & 5 & 90 & Excellent \\
\hline An overall assessment & 24 & 25 & 98 & Excellent \\
\hline
\end{tabular}

The second aspect researcher conducted to identify whether the learning media already fulfilled the linguistics standard to be used in speaking descriptive text for the tenth grade students or not. The data above demonstrated that average percentage of experts' validation toward linguistic aspect researcher $98 \%$ and categorized as excellent. As the result, the media especially in linguistic aspect has been understandable. Additionally, all of the items assessed above were categorized as excellent. Based on those criteria, the Speaking Board Game is an appropriate learning media which is understandable, motivating, efficient and effective in the descriptive text teaching and learning. 
Table 4. 7 The Data of Experts' Validation toward Layout Aspect

\begin{tabular}{|c|c|c|c|c|}
\hline \multirow{2}{*}{ Items Assessed } & \multicolumn{2}{|c|}{ Experts } & \multirow{2}{*}{$\begin{array}{l}\text { Percentages } \\
\qquad(\%)\end{array}$} & \multirow{2}{*}{ Criteria } \\
\hline & $\mathbf{I}$ & II & & \\
\hline Media's appearance is interesting & 5 & 5 & 100 & Excellent \\
\hline The use of font and color are readable & 4 & 5 & 90 & Excellent \\
\hline The use of letter variation is not exaggerating & 4 & 5 & 90 & Excellent \\
\hline $\begin{array}{l}\text { Pictures or illustrations given in line with the } \\
\text { instructions. }\end{array}$ & 5 & 5 & 100 & Excellent \\
\hline $\begin{array}{l}\text { The use of pictures/illustrations is aesthetic and } \\
\text { functional }\end{array}$ & 4 & 5 & 90 & Excellent \\
\hline An overall assessment & 24 & 25 & 94 & Excellent \\
\hline
\end{tabular}

The last aspect researcher used to identify the relevancy of the layout, including the fonts (size, color), background, color used and pictures or illustrations used in the media whether the pictures are in line with the tourist attractions or historical buildings being described. As the result, the percentages of validating the layout aspect for the media researcher categorized as excellent (94\%).

Table 4. 8 The Result Data of Experts' Validation of Speaking Board Game

\begin{tabular}{cccl}
\hline No & Item Assessed & Validation (Percentages & Criteria \\
\hline 1 & Indicator Aspect & 93.3 & Excellent \\
2 & Linguistic Aspect & 98 & Excellent \\
3 & Layout Aspect & 94 & Excellent
\end{tabular}


The above table presented that the average percentage of the experts' validation is $95.1 \%$ which is categorized as excellent. Based on the result, it can be stated that Speaking Board Game is an appropriate

\section{Revising}

There were some revisions as suggested by experts.

a) Indra Hartoyo, S.Pd., M.Hum suggested as follow;

"The overall aspects of a good learning media has been well fulfilled. The learning media encounters the students' needs in learning descriptive text. I suggest you to make the clues for the places the students might not know to anticipate if they are

\section{Final Product}

After revising the media, then the final product had been released based on the students' need. This media had been tested and admitted by the experts as an appropriate media to learn speaking descriptive text. It can increase the students' motivation to speak and help them to describe the tourist attractions and historical buildings more easily. Furthermore, this media can be a sustainable asset in comprehending descriptive text for the students.

\section{DISCUSSION}

As stated earlier, the aim of this study is to develop a learning media namely Speaking Board Game based on the students' need that will be an appropriate media in improving students' ability in speaking descriptive text. This study researcher conducted because the absence of fascinating learning media in MAN 1 Medan especially for the tenth grade students. By this reason, many students have less motivation and confident to speak especially in descriptive text material.

In developing Speaking Board Game, the researcher had followed some stages proposed by Borg and Gall (2003). The stages consisted of gathering the information needed, analyzing the students need, designing the media, validating to media to teach speaking descriptive text for the tenth grade students at MAN 1 Medan due to the relevancy of the media to the students' needs, syllabus and learning objectives in descriptive text material.

not familiar with the place in the speaking board game."

b) Nikmah Fadillah Nasution, S.Pd suggested as follow;

"The learning media you have designed is highly relevant with the syllabus especially the learning objectives the students are about to achieve in descriptive text material. I suggest you to produce more speaking board game and promote this to more English teachers to help them conditioning an interractive teaching and learning activity."

experts, revising the media and releasing the final product. All of the steps were successfully done and getting the final product. The final product is based on the students' need and syllabus and appropriate to learn speaking descriptive text. It enables the students to describe the tourist attractions and historical places and increase their knowledge about decsriptive text.

The developed media in this study are relevant with some previous studies. The previous studies also proved that speaking board game can increase the students' motivation in learning English especially speaking skill. Based on the research conducted in 2017 in SMPN 2 Wungu where this research aimed at improving the speaking learning process of the eighth graders of SMP Negeri 2 Wungu through Board Game "Snake and Ladder" in the academic year of 2016/2017 resulted in a significant result. It is concluded that speaking board game can make students improve their speaking skill. With this game, the students can make a descriptive text orally. The students also feel confident when they come forwards in front of the class and able to speak up in front of the class confidently. Moreover, Susanti and Amri (2016) also stated some following advantages of speaking board game to teach descriptive text such as the students have good respond to the teacher. Second of all, the game makes the students feel joy because the game in Board 
Game "Snake and Ladder" is easy to play. Third, using Board Game "Snake and Ladder" researcher easy to implement in the class. This game makes the lesson understood well by the students. This means that by using Board Game media helps the students to comprehend the material clearly and easily because the media facilitate the students to catch the content well. Fourth, using Board Game "Snake and Ladder" makes students more active to speak up. It means that by using Board Game "Snake and Ladder" in teaching speaking make the students active to follow the teaching and learning process

In measuring the validity media, there were two experts who involved in this study as an English lecturer of Medan State University and an English teacher at MAN 1 Medan. The validation result consisted of three aspects, there are indicator aspect, linguistic aspect and layout aspect. Based on those aspects, the experts had validated the media which is categorized excellent in which the average percentage of those aspects is $95.1 \%$. By seeing the percentage, it can be concluded that overall the Speaking Board Game has fulfilled some standards and students' need on speaking descriptive text for tenth grade of students at MAN 1 Medan.

However, the media si not perfect enough. There are several things should be improved. Moreover, there are also suggestions by experts about the learning media. The experts suggested that the places clues added in order to anticipate the students get unfamiliar with the tourist attractions or historical buildings in the speaking board game. Therefore, there will be no problem when playing the game and ease the students to describe the places.

At the final, this study is purposed to remind the teacher that the use of media is highly important to attract the students' attention to learn and help them comprehend the material easily. In this case, Speaking Board Game can be an alternative media to support the teaching and learning process of descriptive text material in the classroom. Kamaludin (2009) stated that media is facilities, resources or toold used by people to produce message or information. It can be any components that students used to convey messages in order to build their motivation to learn.

\section{CONCLUSION}

After analyzing the data taken from the research conducted in MAN 1 Medan, the conclusions can be drawn as follow:
1. The existing learning media used in the teaching of descriptive text by the teacher is not interesting and not contributing toward students' speaking ability. It can be shown from the result of teacher interview that the teacher only used Realia (a kind of miniature) or by showing slides containing the picture of tourist attractions and historical places to teach descriptive text.

2. The learning media in this study is developed based on the students' needs and following the design of Research and Development (R \& D). It is concluded that the tenth grade students at MAN 1 Medan faced some problems in descriptive text that the students are unable to speak the descriptive text. Additionally, the teaching and learning process is not supported by an interesting learning media to motivate the students to be more confident in speaking decsriptive text. Therefore, the students need a learning media to help them in the form of game. In this case, speaking board game is expected by most students of tenth grade at MAN 1 Medan as their learning media in speaking descriptive text. It is assumed that speaking board game is the solution for the students' learning problem. Developing Speaking Board Game as a media in learning speaking descriptive text followed the $\mathrm{R}$ \& D phases by Borg and Gall (2007) which is simplified into, (1) Gathering Data and Information; (2) Need Analysis; (3) Design Media; (4) Validate by Experts; (5) Revision; (6) Final Product. The average percentage of validating the media to the experts is $95.1 \%$ which is categorized as relevant media. It means that Speaking Board Game is valid and appropriate to be used as a media in teaching speaking descriptive text for the tenth grade students at MAN 1 Medan. 